\title{
ISLAMIC ECONOMIC PERSPECTIVES IN BUYING IN THE TRADITIONAL MARKET TUESDAY PANAM TAMPAN KOTA PEKANBARU (Analysis of Business Ethics)
}

\author{
Nurhadi \\ Islamic College (STAI) Al-Azhar Pekanbaru Riau \\ Email: alhadijurnal@gmail.com
}

\begin{abstract}
This study aims to determine the review of Islamic economics related to business ethics in buying and selling transactions in the traditional market of Selam Panam, Tampan District, Pekanbaru City. The subject of research for traders, the object of business behavior. Data collection techniques with observation, interviews and documentation. Analysis of the data is descriptive analysis where the data obtained is analyzed and presented in the form of an analysis table. Based on the results of observations and questionnaires obtained from traders, there are several points of business ethics that are applied, namely halal, trustworthiness, justice, non-coercion and endorsement, so this is in line with business ethics in buying and selling transactions according to the Sharia Economy. However, at honest and usury points there are still fraudulent actions that are not appropriate. So it can be concluded that business ethics in buying and selling transactions in the traditional markets Tuesday Panam Tampan Pekanbaru which are reviewed according to the Sharia Economy in general have not been well implemented by traders. Traders still commit fraud (reducing doses, hiding defects of goods, and others), this is contrary to Islamic law.
\end{abstract}

Keywords: Perspective, Islamic Economics, Business Ethics, contract, Buying and Selling.

\section{INTRODUCTION}

Economics is a unit that cannot be separated from the values that surround it. Economics has connections and dialectics with the social and cultural values of society, even the economy transmits its potential power, influences and shapes the reality or environment in which the economy is practiced (Muhammad, 2014:2). While the market can simply be interpreted as a meeting place for sellers and buyers to make transactions (Kasmir, el, 2010: 43).

Market economy is an economic system that is controlled, regulated and directed by the market itself. Regulations in the production and distribution of goods are entrusted to the mechanism itself. This type of economy comes from an expectation that humanity will take a position in such a way as to gain as much profit as possible. 
This economic system considers the market as a place for the supply of goods, including services, at a certain price based on that price will meet demand (Damsar, 2012: 84).

In such a market system, consumers are an important factor and determine the position of the market. Consumers will determine the goods and services they want, in other words, there is interdependence between traders and buyers (Nejatullah, 2016: 81).

Ethics is a scientific discipline that provides knowledge of what is right and what is wrong. Ethics as a science that can be interpreted as moral values and norms in a society (Harahap, 2011: 69).

Ethics has a very important position in human life, both as individuals, members of society and members of a nation (Wati, 2018). Ethics comes from Latin ethos which means 'habits', synonyms are moral, also comes from the same language 'mores' which means 'habits'. Whereas the Arabic form of jama 'morality from the mufradatnya khuluq means manners. Both can be interpreted as habits or customs that show human behavior itself, actions or attitudes that are considered right or good (Hasan, 2016: 171-172).

Business is the exchange of goods, services or money that are mutually beneficial or provide benefits. Simply business is all activities carried out by someone or more organized in seeking profit through the provision of products needed by the community (Tantri, 2015: 4).

Islamic ethics that characterizes the Islamic economic system intends to explain that Islam as a way of life is a form of worship. So that no one can assume that Islam only focuses on aspects of religious rituality, without the social-economic aspects that surround it. Islamic economics ethically intends to combine world and hereafter problems (Aziz, 2013: 97).

In Islamic economics, business and ethics do not have to be seen as two things that are contradictory, because business is a symbol of worldly affairs, also considered as an integral part of investment matters hereafter. That is, if business orientation and endeavor interval (intended as worship is the totality of obedience to god), business must itself be in line with moral principles based on faith in the hereafter. Even in Islam the notion of business is not limited to world affairs, but includes all activities in the world that are business (intended as worship) to reach profit or reward hereafter (Aziz, 2013: 97-98).

Panam Tuesday Market is located in Tuah Karya Village, one of the villages in 
Tampan District. The crowded market on Tuesday is crowded with local and outside traders such as traders from Kampar. The people who shop at the market are not only from Tuah Karya Village, but many also come from outside the kelurahan even outside Tampan District.

In general, the market consists of two types, namely traditional markets and modern markets. So the market that researchers want to study is the new intersection market in the Tuah Karya sub-district, Tampan sub-district, Pekanbaru, which is a category of Traditional Markets.

From the author's observation, there are still many traders who ignore ethics in running their business. Still many traders do deviations in trading. Some of the deviations found in the traditional market, for example the reduction of scales and doses, mixing good quality goods with bad ones, traders who provide poor service and dropping each other merchants (Observation, 2017).

The fact that has happened in the Market towards current trade ethics is that there has been an ethical shift in trade or business. So far, traders understand business is a business, which aims to get as much profit as possible by justifying any means to gain profit (Wati, 2018). Traders still do not understand the ethics applied by Islam, because lack of understanding, traders do not realize the importance of trading with appropriate ethics in Islam (Putra, 2017).

Some traders experience many obstacles when they know the condition of the goods experiencing defects. Traders have difficulty in this case, because if explained to the buyer, the sword will suffer losses due to not selling. And some buyers sometimes don't ask about the condition of the item (Putri, 2017).

This is reinforced by the statement of selasa traditional market customers who have gotten fraudulent scales in shopping. One of them was the confession of the mother, that she bought $1 \mathrm{~kg}$ of fruit, when she wanted to buy different fruits in different places with the same weight of $1 \mathrm{~kg}$, there was a difference in the two fruits she bought, then she weighed the first fruit and it turns out it is less than one ounce of the actual dose (Fatimah, 2017).

This phenomenon illustrates that some traders in the traditional market of Panam Tuesday still lack implementation of Islamic business ethics. They are still oriented to worldly benefits and abandon business ethics (Wati, 2018).

Based on the background of the problem above, the researcher will formulate a problem in the form of a question, namely: how to review Shariah Ecomoni on business ethics of market traders during the new intersection of the Tuah Karya sub-dis- 
trict of Tampan sub-district of Pekanbaru in the sale and purchase transaction ?.

\section{METHODS}

The location of this study is the new selang simpang market trader in Tuah Karya sub-district, Tampan sub-district, Pekanbaru. Furthermore, this research was carried out to the traders in the location. This location was chosen because the author wanted to review or want to know the merchant business ethics in the sale and purchase transactions carried out in the market, according to the eyes of Islamic business ethics. The subjects in this study were sellers of the new intersection of the Tuah Karya village in Tampan sub-district, Pekanbaru city. While the object of this research is business ethics according to Islamic economics. Population is the total number of units of analysis, namely the object to be studied. While the sample is a part of the population that will be studied and which will be considered to be able to describe the population (Soehartono, 2014: 57).

This study uses two data, namely primary data is data obtained directly from the market of the new intersection of Tuah Karya sub-district, Tampan sub-district, Pekanbaru and also data that is not yet available and to obtain the data researchers must use several research instruments such as questionnaires, interviews, observation and so on (Tanjung, el, 2013: 76). And secondary data is data obtained from the second source or secondary source from the data we need (Burhan, 2015: 132). The data is in the form of books, magazines, internet related to marketing.

Methods of collecting data by means of observation and interviews. Observation is a method of collecting data by direct observation in the field to get a real picture of the activities to be studied. Interview is direct interaction and communication, the purpose is to obtain valid and accurate data. The analysis used in this study is Qualitative Descriptive analysis, qualitative data derived from observations, interviews and questionnaires which are explained by connecting between one fact and the other facts then the data is analyzed for conclusions.

\section{RESULTS AND DISCUSSION}

\section{Historical Traditional Panam Tuesday Market}

The traditional market of Selasa Panam was originally known as the new intersection market because it was located in a new intersection, but over time the market was crowded by people, but this market was more crowded on Tuesday than in other ordinary days so people called it or better known as the Panam Tuesday market. In 2000 the division of the kelurahan took place so the Pekanbaru Panam tuesday market was taken over by the village of Tuah Karya because the Panam tuesday market 
was located in a sub-village of several works to date (Wati, 2018).

According to the head of the Pekanbaru UPTD, the community of the Pekanbaru Market Panam Pekanbaru traders according to the place of sale can be seen in the table below.

Table I

Number of Traders by Place of Business in 2017

\begin{tabular}{|c|c|c|}
\hline No & Place of business & Total (unit) \\
\hline 1 & Stall & 258 \\
\hline 2 & Los & 91 \\
\hline \multirow[t]{2}{*}{3} & Umbrella / Street Feet & 101 \\
\hline & Total & 450 \\
\hline
\end{tabular}

Source: Ka. UPTD Tuesday Market Panam Pekanbaru, 2017

From the data above, it can be seen that the traders who sell the most in the traditional markets of Selam Panam use Kios totaling 258 traders with various types of merchandise.

Based on the type of goods sold by traders in the traditional market of Selam Panam and the number of traders can be seen in the table.

Table II

Number of Traders According to Types of Merchandise in 2017

\begin{tabular}{|c|c|c|}
\hline No & Types of Merchandise & Total \\
\hline 1 & Daily Goods & 30 \\
\hline 2 & Fruits & 20 \\
\hline 3 & Side dishes and vegetables & 175 \\
\hline 4 & Children's toy & 7 \\
\hline 5 & Food and Drink & 50 \\
\hline 6 & Drugs & 10 \\
\hline 7 & Convection & 95 \\
\hline 8 & Household Furniture and Production & 30 \\
\hline 9 & Jewelry and accessories & 20 \\
\hline 10 & Electronic & 10 \\
\hline \multirow[t]{2}{*}{11} & Building tools & 3 \\
\hline & Total & 450 \\
\hline
\end{tabular}

Data: Source of the results of the author's inventory

The market is one of the places where traders and buyers meet, as a place that brings together traders and buyers, so the market becomes a meeting place for a group of people consisting of various ethnic groups, namely the Malay, Javanese, Minang and Batak tribes. But the everyday language they use is Minang, this is because 
the majority of traders and buyers in the Pasar Tuesday Pekanbaru Panam are Minang, even though there are actually other ethnic groups but there are fewer people compared to the Minang tribe.

Education that has been followed by someone is very influential on the determination of the quality of human resources, the higher the education that has been followed by someone, the better the quality of one's resources (Wati, 2018). Formal and non-formal education will be the basis for one's efforts. According to the head of the Pekanbaru UPTD, the community of the Pekanbaru Pasar Panam Pekanbaru traders generally have high school / equivalent education. This can be seen in the table below.

Table III

Education Classification for Tuesday Market Traders in Panam Pekanbaru

\begin{tabular}{clc}
\hline No & \multicolumn{1}{c}{ Alternative Answers } & Frequency \\
\hline 1 & Academy / College & 25 \\
2 & Senior High School / equivalent & 250 \\
3 & SLTP / Equal & 140 \\
4 & Elementary / equivalent & 45 \\
5 & No education & 0 \\
6 & Total & 450 \\
\hline
\end{tabular}

Source: Ka. UPTD Tuesday Market Panam Pekanbaru, 2017

From the table above, we can see that all traders at the same time as Pekanbaru Panam were educated, most of them had upper level education. This is evidenced by 25 traders who have attended lectures, as many as 250 traders who have high school / equivalent education, and 140 traders who have junior / equal education and who have elementary education / equivalent have 45 traders while those without education 0.

Indonesian society is a society that has a wide variety of ethnic groups and religions. Likewise, what is in the city of Pekanbaru consists of various kinds of ethnic groups and religions. Islam does not prohibit people from trading or buying and selling while not in conflict with Islamic religious rules (Wati, 2018).

Tuesday Market Traders, Panam Pekanbaru are traders whose majority are Muslims, there are also non-Muslim traders, but there are very few in number compared to Muslims, both from traders and buyers (Wati, 2018).

\section{Definition of Business Ethics and its Principles}

If traced historically, ethics is a branch of philosophy that seeks the essence 
of good and bad values related to one's actions and actions, which are carried out with full awareness based on consideration of his thoughts. The issue of ethics is a problem related to human existence, in all aspects, both individuals and society, both related to God, with fellow human beings and themselves, as well as with the surrounding environment, both in relation to human existence in the fields of social, economic, polotic, cultural or religion (Ash'ari, 2011: 92).

Meanwhile the business according to the Indonesian rice dictionary is: a). Trading business, making money by trading methods; b). Commercial business in the world of commerce. While the International Encyclopedia states that business is a human activity involved in buying and selling goods and services with the aim of gaining profits (Asy'ari, 2011: 36).

The Business Ethics according to Muslich is the application of general ethics that regulates business behavior, the norm of morality which is a business reference in its behavior. The assessment of business success is not only determined by the success of economic and financial achievements. But that success is measured by the benchmark paradigm of morality and ethical values, especially on morality and ethics which are based on social and religious values. Conceptually, it can be stated that the process of achieving the objectives of a business activity through human management and natural resources is directed at optimizing the management and allocation of resources for all parties or stakeholders (Tantri: 37 ).

In the opinion of Micheal Joseph (1998) cited by Zimmerer (1996: 27-28), universally, there are 10 ethical principles that direct behavior, namely:

a) Honesty, which is full of trust, honesty, truly, honestly, not cheating, not stealing, not stealing, not lying (Anoraga, 2011: 133).

b) Integrity, holds the principle of carrying out activities that are honorable, sincere, courageous and full of convictions / beliefs, not duplicity, do not do evil and can be trusted (Anwar, 2014: 97).

c) Maintain promises, which are always obeying promises, worthy of trust, full of commitment, obedient not interpreting agreements in technical or legalistic terms under the pretext of unwillingness (Anwar, 2014: 97).

d) Loyalty, namely respect and loyalty to family, friends, employees, and the state, not using or showing confidential information, as well as in a professional context, maintaining / protecting the ability to make free and thorough professional decisions, and avoiding things that inappropriate and conflict of interest (Anoraga: 133).

e) Fairness or fairness, which is fair and virtuous, willing to admit mistakes, show commitment to justice, equality of individual treatment and tolerant of dif- 
ferences, and not overreach or take advantage of free and thorough professionals, and avoid things that are not inappropriate and conflict of interest (Anwar: 97).

f) Likes to help others, namely mutual help, kindness, compassion, help, help, togetherness, and avoiding everything that endangers others (Anwar: 98).

g) Respect for others, namely respecting the dignity of others, freedom and the right of self-determination for all people, being polite, not demeaning and treating the dignity of others (Anwar: 98-99).

h) Responsible citizens, namely always obeying the law and rules, full of social awareness, and respecting the democratic process in making decisions (Anwar: 99).

i) Pursue excellence, namely the pursuit of excellence in everything, whether in personal meetings or professional accountability, diligent, trustworthy / reliable, diligently full of commitment, doing all tasks with the best ability, and developing and maintaining a high level of competence (Anwar: 99).

j) Can be accounted for, namely having and accepting responsibility for the decisions and consequences and always giving examples (Anwar: 97-99).

\section{Terminology of Sale and Purchase and other Provisions}

Buying and selling or trading in the term fiqh is called al-bai 'which according to etymology means to sell or replace (Rahman et al. 2010: 67). What is meant is:

a) Exchange goods with goods or goods with money made by releasing ownership rights from one to another on the basis of mutual voluntary.

b) Ownership of property by means of exchange in accordance with the rules of syara ‘

c) Exchange of assets, accept each other, can be managed with ijab and Kabul in a manner that is in accordance with the conditions.

d) Exchange objects with other objects in a special way (allowed)

e) Exchange objects with other objects by mutually giving up or transferring property rights with a substitute in a way that is permissible.

f) A contract that is upheld on the basis of the exchange of property with assets, then the ownership rights are exchanged permanently.

Buying and selling as a means of helping between fellow human beings has a strong foundation in the Qur'an and the sunnah of the Prophet (saw), Rahman et al. 2010: 68). Buying and selling is a contract, and is considered valid if it has fulfilled the pillars and terms of sale and purchase. Regarding harmony and terms of sale and purchase, the scholars differed. These indicators can be in the form of words (consent and obedience) or in the form of actions, namely mutual giving (delivery of goods, and receipt of money). In jurisprudence, this is famous for the term "Bai al-muathah 
(Wati, 2018).

According to the scholars, the pillars of buying and selling are four, namely as follows (Sahrani, el, 2011: 67): 1). A person who is mindful (seller and buyer); 2). Sighat (Lafaz ijab and kabul); 3). There are items purchased; 4). There is an exchange rate for goods.

According to H.A Syafii Jafri in his book entitled Fiqh Muamalah, for the validity of buying and selling that is done, it takes several pillars and the conditions that must be fulfilled are: 1). Sellers and Buyers, namely understanding, for those who are crazy, stupid and others are not authorized to buy and sell. Own will not be forced. The condition is not redundant (wasteful), people waste their assets under the guardian. 2). Money and objects traded with conditions: Holy, unclean illegitimately made money and illegally sold. Useful, may not sell objects that have no benefits. Can be mastered and can be handed over, not selling birds that are flying in the air. The objects and prices belong to the seller and the buyer or as a representative. Buyers and sellers know about substances, shapes, levels (sizes) and the properties of these objects. 3). Sighatul akad, that is the way in which ijab and Kabul which are the pillars of the contract are stated. Sighat akad can be done by way of oral, written or gesture that can provide a clear understanding of the existence of ijab and Kabul, besides that sighat akad can also be acts that have become habitual acts in Kabul ijab (Syafii, 2014: 46-47).

\section{The meaning of market terms and ins and outs}

The market can be interpreted as a place where buyers and sellers meet to exchange their goods, such as a village square. Economists use market terms to express a group of buyers and sellers who make transactions on a particular product or class of products, such as the housing market, large markets and others. Whereas in marketing management the market concept consists of all potential customers who have certain needs or desires that may be willing and able to involve themselves in an exchange to satisfy certain needs or desires that may be willing and able to involve themselves in an exchange to satisfy those needs or desires. In the past, markets referred to geographical locations, but now the market no longer has geographical boundaries because modern communication has enabled buyers and sellers to hold transactions without having to meet each other (Mujahideen, 2014: 141).

The market has a function as a determinant of the value of an item, determining the amount of production, distributing products, limiting prices, and providing goods and services for the long term (Wati, 2018).

Traditional markets are places that are built and managed by the Government, 
Local Government, Private Sector, State-Owned Enterprises, and Regionally-Owned Enterprises which are meeting places for sellers and buyers in the process of buying and selling transactions in the form of retail and usually bargaining processes and buildings. consists of kiosks or outlets, booths and open bases opened by sellers and market managers (https://www.google.com, 2018).

Most sell daily necessities such as food ingredients in the form of fish, fruit, vegetables, eggs, meat, cloth, clothing, electronic goods, services and others. In addition, there are also those who sell cakes and other items. Traditional markets usually exist in a temporary or fixed time with a limited service level. Such markets can generally be found in residential areas to make it easier for buyers to reach the market (Wati, 2018).

\section{The Perspective of Business Ethics in Islamic Economics at the Panam Tues- day Market}

Islamic business ethics is a process and effort to find out the right and wrong things which in turn certainly do the right thing with regard to the product, service the company with parties with an interest in the provisions of the company. In discussing Islamic business ethics it involves "Business Firm" and / or "Busness Person", which has varied meanings. Doing business means a profitable business. So Islamic business ethics is the study of someone or organization doing business or mutually beneficial business contacts in accordance with the values of Islamic teachings (Aziz: 35).

Islam not only regulates human relations with God, but also provides a spirit of value awareness that animates all human activities. Even in matters relating to world affairs (economics and business), humans are given autonomy to make decisions that favor human well-being as Allah's caliph on the earth (Muhammad, 2014: 64).

There are several important things related to the basis of ethics in Islamic business, to analyze what happened at the Panam Pekanbaru Market, which is related to (Wati, 2018):

1) Honest. Shidiq (honest) is the nature of the Prophet Muhammad, which means heavy and honest. A trader must be honest in his business of buying and selling, honestly in a broad sense does not lie, do not cheat, do not make it up, facts, do not betray, and never break promises and so forth. Honestly generally acknowledged as the first and most important virtue that business people must have. In determining the implementation of honesty of business ethics in buying and selling transactions in the traditional market of Selasa Panam, Tampan District, Pekanbaru City, can be seen from several things, among others: a). Goods Defects. The results of observations and interviews with traders can be concluded 
that business ethics in buying and selling transactions in the traditional markets of Panam Subdistrict, Tampan District, Pekanbaru, regarding honesty in defects in goods are not yet in accordance with Islamic economics. b). Gharar. After observations that researchers did in the traditional market, Selam Panam, Tampan District, Pekanbaru City. Traditional market traders during panam Tampan Subdistrict, Pekanbaru City regarding the feasibility of merchandise, such as food vendors, vegetables, fruits, meat, fish, clothing, tofu and tempeh, daily goods, and cosmetics are in accordance with Islamic economics. This is evident because traders sell good goods and are in good condition, traders never sell stale or inappropriate items. In terms of lack of clarity of goods in terms of the condition of merchandise that occurs in traditional markets as long as the subdistrict subdistrict, handsome city Pekanbaru, from the author's observation that it is in accordance with Islamic economics. c). Item manipulation. The result is that there is still fraud occurring in the traditional markets of Panam Tuesday Tampan District, Pekanbaru City. And this is not yet in accordance with Islamic economics. d). Reducing scales. The result is that business ethics in buying and selling transactions in traditional markets Tuesday Panam District Tampan Pekanbaru City regarding honesty in measuring scales is not in accordance with the Sharia Economy.

2) Halal. Al-qur'an has firmly laid out the basic concepts of halal and haram which relate transactions in trade. According to Mustaq Ahmad as quoted by Muhammad Djakfar (2016: 98), all matters relating to property should be seen and punished with both halal and haram criteria. Mecca people who lived in the era of the Prophet did not distinguish between business and usury. For them both are the same. Finally the Qur'an builds the concept of halal and haram by affirming that buying and selling is legal, while usury is forbidden. The prohibition of usury in any form or name because it is a tyranny of others so that it hurts the sense of justice. Because all forms of transactions carried out with evil practices are prohibited by Islam. All prohibitions are based on a principle "do not have injustice and do not have fraud in all buying and selling activities carried out by anyone, the essence of unlawful business is a business in which contains non-halal consumption, or violates and seizes rights and wealth others (Ahmad, 2013: 125). Practices that occur in traditional markets Tuesday Panam Tampan District Pekanbaru City through the results of the author's observation of halal merchandise that is not found traders who sell goods that are forbidden to buy and sell. In the trade of goods, although it is a bit unclean or subhat nothing is sold which is important and can meet family needs, such things have never been done by traders such as mixing dead chickens before being cut (slaughtered) with chicken that has been cut in sales or fish mixed with formalin (preservative) to be durable and long lasting. The author does not find anything that is unclean for sale, traditional market traders Selasa Panam Tampan district Pekanbaru City like chicken traders have nev- 
er sold chickens that have died before being slaughtered to the buyer because chicken traders will slaughter the chicken when there are buyers who buy, as for chickens already slaughtered in advance is for traders who buy small quantities of chicken and the chicken is slaughtered that day and in small amounts. This argument is reinforced by the statement of the buki dewi buyer and buk fatiah as the permanent buyers of traditional markets Tuesday, Panam, Tampan District, Pekanbaru City. These two shops feel comfortable in shopping and are not worried about the halal goods they are going to buy because they see firsthand the process of cutting the chicken. According to Ibuk Fatiah, "I will not be worried if I shop chicken at the selasa market because I believe that the chicken I bought is halal, I have often shop here and know the cutting process" (Fatiah, 2018).

3) Trustworthy. Amanah in Indonesian is trustworthy. Trust is a very valuable asset in the business world (Sunyoto, 2015: 45). Amanah has the meaning of responsibility in carrying out every task and moral obligation imposed on everyone, both in carrying out the task of servitude to God and the task of humanity among each other (M.Nur, 2010: 27). In management principles, trust is a very important keyword, until a business process is handled honestly, transparently, and accountably (Djunaidi et al., 2013: 56). Based on the results of observations that the authors did on the traditional market Tuesday Panam Tampan District Pekanbaru City regarding trust, there are still traders who are not trustworthy to buyers. Where the merchant offers his merchandise with an oath. But when the buyer complains, some traders do not receive complaints after the item is purchased. The merchant dodges to exchange the item because it will suffer a loss if the trader exchanges the item, because the item exchanged cannot be sold back. As in an interview with market traders, Buk Rida said that this was already known to the public. Where traders often promise to replace if the goods are damaged, but when the goods are damaged, traders argue that the goods have arrived home, it has been several days and so forth (Efrida, 2018).

4) Justice. In the book Ihya Ulumuddin Imam Al-Ghazali as followed by poleh Yusuf Bin Ismail An-Nabhani in his book "Beware of the Market AdaSan", in fact Allah has asked for an attitude of justice and ihsan. Because fairness is a way of safety in commerce it functions as capital. While tolerance is the way to achieve victory and profit. Of course, it is said to include people who have sense who are satisfied with the return of capital in various world transactions. And so it is with various transactions hereafter (Yusuf, 2015: 47). From the results of the author's observation, that justice in the Tuesday market in Panam Subdistrict, Tampan, Pekanbaru City is in accordance with the Sharia Economy. The traders in the market on Tuesday did not discriminate between buyers with each other. Traders do not select buyers and serve buyers equally. As for merchant types of convection, traders conduct a negotiation process regarding the price of goods. This makes the dif- 
ference because each person's negotiations are different. This type of merchandise convection in terms of attracting buyers is the process of bargaining, so the results of each buyer can be different. But this is not included as unfair, because the needs and quality of each person is different so the bargaining results will be different.

5) Not Forcing. Many people are difficult to behave kindly among others. Often surly when meeting people he doesn't like or choosing to behave in an unfriendly manner. In fact, friendliness is the commendable nature that is recommended by Islam for anyone and for anyone. Friendly, many people like it, with many friendly people who are happy. Because friendly nature is a form of application of someone's humility. Generous, not feeling arrogant, wanting to respect and love are at the core of being friendly. Therefore, be friendly in buying and selling transactions because it can make consumers happy so they feel at home or even feel at ease when doing transactions. As a result, traditional market selasa selasa Panam Subdistrict of Tampan, Pekanbaru City did not force the buyer and this was in accordance with the Sharia economy.

6) Summary. Don't hoard merchandise when people are in need with the aim of getting as much profit as possible. Hoarding of goods is the biggest obstacle in the regulation of Islamic market competition, this is due to its influence on the amount of goods stockpiled, where traders choose to hold their merchandise and not sell it because of waiting for price increases (Hakim, 2012: 168). Through the results of observations that the author did in the traditional market of Selam Panam, Tampan Subdistrict, Pekanbaru, about the practice of hoarding goods, the traditional market selasa Panam traders did not practice ikhtikar. Manggimbun here is deliberately stacking goods to take large profits. The result is that the traditional market selasa selasa Panam Kecamatan Tampan Kota Pekanbaru does not carry out stockpiling, this is in accordance with the Sharia economy.

7) Usury. The Prophet taught that traders always be fair, good, cooperation, trust, trust, qana'ah, patience, and courage. On the contrary, he also advised that merchants leave the gross nature of trade, which only gave a momentary advantage, but harbored worldly and ukhrawi self-harm. As a result the credibility is lost, the customer runs away, and the next confusion is narrow (Mujahideen: 169). The result is that the practice of usury is still and occurs in the Panam Tuesday Market, where providing loans to traders who are in need by providing relief in paying is by installments, then taking advantage of many of the borrowed basic assets for various reasons.

\section{CONCLUSION}

Based on the results of the research and discussion that has been carried out 
can be drawn some conclusions from business ethics research in buying and selling transactions in Traditional Markets Tuesday Panam Tampan District Pekanbaru City reviewed according to the Sharia Economy as follows: That on Halal, Trustworthy, Justice, Non-Forces and Ikhtikar Points is appropriate with Business Ethics in Buy and Sell transactions according to the Sharia Economy. However, on Honest and Riba points there are still fraudulent actions that are not in accordance with Business Ethics in Buy and Sell Transactions according to the Sharia Economy. Based on the observations obtained from the traders in traditional markets Tuesday, Panam, Tampan Subdistrict, Pekanbaru City, which was reviewed according to the Sharia Economy in general, had not been well implemented by traders. This can be seen in the results of observations and supported by interviews that the authors did, namely the traders still did not apply honesty in buying and selling, traders still did not explain the condition of the goods (goods defects), and the traders still cheated on the measure, which is to reduce the amount scales for greater profit. Forcing buyers to buy and still practice usury. In the Islamic view the aspects of fraud above are not in accordance with the Islamic economy.

\section{REFERENCES}

Abdullah, Maufuf. 2011. Sharia-Based Entrepreneurship. Banjarmasin: Antasari Press.

Religion, Ministry of RI. 2015. al-Qur'an and the Translation Bandung: Syaamil Cipta Midya.

Ali, Kamal. 2017. Doing business with Cara Rasul. Bandung: Jember.

Alma, Buchori and Donni Juni Priansa. 2014. Sharia Business Management. Bandung: Alfabeta.

Alma, Buchori. 2014. Fundamentals of Islamic Business Ethics. Bandung: CV. Alfabeta. Alma, Bukhori. 2013. Sharia Business Management. Bandung: Alfabeta

An-Nawawi, Imam. 2013. Muslim Syahih. Jakarta: Darus Sunnah Press.

Anoraga, Pandji. 2011. Introduction to Business. Jakarta: PT Rineka Cipta.

At-Tarmizi. 1426 H. Sunan At-Tarmizi, Juz 3, Hadith number 1209, CD Roo, Maktabah of Al-Mutun Pole, Al-ImIlm An-Nafi 'Lineage, Series 4, Al-Ishdar Al-Awwal.

Aziz, Abdul. 2013. Business Ethics Islamic Perspective Implementation of Islamic Ethics for the Business World. Bandung: Alfabeta

Aziz, Abdul. 2013. Business Ethics Islamic Perspective, Implementation of Islamic Ethics for the Business World. Bandung: Alfabeta.

Azwar, Adiwarman, Karim, 2018. History of Islamic Economic Thought. Jakarta: 
Raja Grafindo Persada.

Badroen, Faisal. 2016. Business Ethics in Islam. Jakarta: Kencana.

Basri, Helmi. 2010. Worship Jurisprudence. Pekanbaru: Suska Press.

Binbaz. 2018. http://www.binbaz.org.sa/mat/19167. Accessed on April 17, 2018, 10.00 WIB.

Burhan, M. Bungin. 2015. Quantitative Research Methodology. Jakarta: PT. Kencana Prenada Media Group.

Burhanuddin. 2015. Individual Ethics Archetype of Moral Philosophy. Jakarta: PT. Rineka Cipta.

Damsar. 2012. Economic Sociology. Jakarta: PT. Raja Grafindo Persada.

Efrida, (Trader). 2018. Interview with Panam Tuesday Market, (January 5)

Fatiah, (Buyer). 2018. Interview, Tuesday Panam Market, (January 17)

Fatimah, Hamdan, (Buyer). 2017. Interview, Tuesday Market Panam, (Panam, 12 December)

Google. 2018. https://www.google.com/amp/s/niaas8.wordpress.com/ understanding of-pasar-tr Tradisional-dan-modern/amp/. Accessed on 1 January 2018, 19.00 WIB.

Judge, Lukman. 2012. Principles of Islamic Economics. Surakarta: Erlangga.

Harahap, Sofyan S. 2011. Business Ethics in the Islamic Economic Perspective. Jakarta: Salemba Empat.

Harahap, Sofyan S. 2011. Business Ethics in the Islamic Perspective. Jakarta: Salemba Empat

Hartono. 2014. Statistics for Research. Yokyakarta: Student Library.

Hasan, Ali. 2012. Rich World Sharia Business Management in the Hereafter. Yogyakarta: Student Library.

Hasan, Ali. 2016. Rich World Islamic Business Management Honored in the Hereafter. Yogyakarta: Student Library

http://suratmelita.blogspot.co.id/2016/09/makalahpasartitusidanpasarmodernpendidikan-ips-socialekekidownload-elitasmipertian understanding-Benefitsconsequences-indonesia-keuangan.html?m=1. Accessed on 1 January 2018 19.20 WIB.

Jakfar. 2013. Business Feasibility Study. Jakarta: PT. Kencana Prenada Media Group. Jusmaliani. 2012. Syari’ah Based Business. Jakarta: Bumi Aksara.

Kadir. 2010. Sharia Business Law in the Qur'an. Jakarta: Amzah. Kasmir, and Jakfar. 2010. Business Feasibility Study. Jakarta: Kencana. 
Majah, Ibnu. 1426H. Sunan Ibnu Majah, Juz 2, Hadith number 2139, CD Room, AlMutun Polabah, Al-?allm An-Nafi 'Lineage, Series 4, Al-Ishdar Al-Awwal.

Malik, Imam, bin Annas. 2016. Al-Muaththa 'Imam Malik, Translator Muhammad Iqbal Qadir. Jakarta: Library Azzam.

Mardani. 2013. Sharia Economic Law. Jakarta: PT Fajar.

Mhd. Nuruddin, Ali. 2016. Zakat as an Instrument in Fiscal Policy. Jakarta: PT Raja Grafindo Persada.

Miftahul, H. Huda. 2017. Economic Aspects in Islamic Sharia. Mataram Consultation and Legal Aid.

Muhammad, Sheikh, Yusuf Qardhawi. 2017. Halal and Haram in Islam. Surabaya: PT Bina Ilmu.

Mujahideen, Akhmad. 2014. Islamic Economics (History, Concepts, Instruments, Countries, and Markets). Jakarta: PT raja Grafindo Persada.

Mursida, Umi. Application of Islamic Business Ethics in Buying and Selling Transactions in Traditional Markets (Case Study of the Betung Market in Sekincau District, West Lampung Regency), Journal of Islamic Economics.

Natadipurba, Chandra. 2016. Islamic Economics 101. Bandung: PT Mobidelta Indonesia. Nejatullah, Muhammad, Siddiqi. 2013. Economic Activities in Islam, translated by Anas Sidik. Jakarta: Bumi Aksara

Observation. 2017. Tuesday Panam Market, (12 December)

Son, Doni, (Bill Clerk). 2017. Interview, Tuesday Panam Market, (December 19)

Daughter, Yuliza. 2017. (Market Traders), Interviews, Tuesday Market Panam, (Panam, 12 December)

Qardhawi, Yusuf. 2011. Norms and Ethics of Islamic Economics. translated by Zainal Dahlia Husin. Jakarta: Gema Insani Pers.

Rahman, Abdul, Ghazaly, et al. 2010. Muamalah Fiqh. Jakarta: Kencana.

Rahman, Afzahul. 2011. Doctrine of Islamic Economics. Yogyakarta: Dana Bakti Wakaf.

Riva'l, Veithzal. 2012. Islamic Marketing (Building and Developing Businesses with the Marketing Practices of the Messenger of Allah). Jakarta: PT. Gramedia Persada Utama.

Rumaysho. 2018. Fraud and deception in buying and selling. https://rumaysho. com/7154-fraud-and-pengelabuan-dalam-jual-beli.html. Accessed on April 17, 2018, 10.00 WIB.

Sahrani, Sohari and Ru'fah Abdullah. 2011. Muamalah Fiqh for UIN / IAIN / STAIN / PTAIS and General Students. Bogor, Ghalia Indonesia. 
Soehartono, Irwan. 2013. Social Research Methods. Bandung: PT. Teenager Rosdakarya

Sugiono. 2013. Quantitative, Qualitative and Combined Research Methods. Bandung: Alfabeta.

Suhendi, Hendri. 2015. Muamalah Fiqh (Discusses Islamic Economy, Property Position, Property Rights, Sale and Purchase, Bank Interest and Usury, Musyarakah, ljarah, Business Ethics etc.). Jakarta: PT Raja Grafindo Persada.

Suwiknyo, Dwi. 2010. Compilation of Interpretations of the Verses of Islamic Economics. Yogyakarta: Student Library.

Syafei, Rachmat.2010. Muamalah Fiqh. Bandung: Loyal Library.

Syafi'i, Imam, Abu Abdullah Muhammad bin Idris. 2016. Summary of Kitab al-Ulum, translated by Amiruddin. Jakarta: Library Azzam.

Syafii, H.A. Jafri. 2015. Muamalah Fiqh. Pekanbaru: Suska Pres.

Tanjung, Hendri \& Abrista Devi. 2013. Islamic Economics Research Methodology. Jakarta: Gramata Publishing.

Tanjung, Hendri and Abrista Devi. 2013. Islamic Economics Research Methodology. Jakarta: Gramata Publishing

Tantri, Francis. 2005. Introduction to Business. Jakarta: Rajagrafindo

Tantri, Francis. 2014. Introduction to Business. Jakarta: PT Raja Grafindo Persada.

Umar, Hussein. 2015. Research Methods for Thesis and Business Thesis. Jakarta: Raja Grafindo Persada.

Wardi, Ahmad, Muslich. 2010. Muamalat Fiqh. Jakarta: Amzah

Wati, Soleh. 2018. Business Ethics in Sale and Purchase Transactions in Traditional Markets Tuesday Panama of Handsome Sub-District of Pekanbaru City Viewed According to Sharia Economy, Islamic Economics Department Faculty of Sharia and Law Sultan Syarif Kasim Islamic State University Riau, $1439 \mathrm{H}$.

Yunia, Ika, Fauzia. 2013. Business Ethics in Islam. Jakarta: Kencana.

Yusuf, Bin Ismail An-Nabhani. 2015. Watch out at the market there is Satan, in Muhammad Al-Mighwar, Jakarta: Your service.

Olive. 2016. Juornal Islamic Law For Islamic Law, Faculty of Sharia and La 